\title{
Unveiling the Implicit Political Agenda: A Comparative Analysis of the Construction of Gender Roles in Grimm's Ashputtel and Giuseppe Pitré's The Magical Little Date Tree
}

\author{
Esin $\mathrm{KUMLU}^{1}$ (1)
}

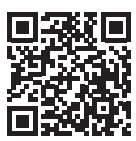

${ }^{1}$ Asst. Prof., Dokuz Eylül University, Buca Faculty of Education, Department of English Language Education, Izmir, Turkey

ORCID: E.K. 0000-0002-6884-6382

\section{Corresponding author:}

Esin KUMLU,

Dokuz Eylül University, Buca Faculty of Education, Department of English Language Education, Izmir, Turkey

E-mail: esinkumlu@yahoo.com

Submitted: 22.01 .2020

Revision Requested: 20.03.2020

Last Revision Received: 06.04.2020

Accepted: 14.04.2020

Citation: Kumlu, E. (2020). Unveiling the implicit political agenda: a comparative analysis of the construction of gender roles in Grimm's ashputtel and giuseppe pitrés the magical little date tree. Litera, 30(1), 155-175.

https://doi.org/10.26650/LITERA2020-0006

\begin{abstract}
In 1981, American therapist Colette Dowling proposed the term "the Cinderella Complex" to the field of psychology to investigate how millions of women have fallen into the trap of the hidden fear of independence. Deriving its name from the fairy tale Cinderella, the term also has begun to elucidate how the discourse of fairy tales has created a 'nonconscious ideology' and designates gender roles in society throughout the ages. In relation, this study scrutinizes the comparative analysis of the Brothers Grimm's fairy tale Ashputtel (1812), widely known as Cinderella, and Giuseppe Pitré's The Magical Little Date Tree (1875), the Italian version of Cinderella, through the lenses of plural investigation methods which encapsulate the feminist literary criticism and the cultural materialist approach. It analyzes how the dominant ideology, the patriarchal discourse represented by the Brothers Grimm through Cinderella, constructs a nonconscious ideology to subjugate women to become passive, weak, submissive entities, not only in fairy tales but also in daily life. This study suggests that the hegemony of the dominant ideology is reversed by Pitré's protagonist Ninetta, who subverts gender roles through creating a language, a voice of her own and encouraging her sense of independence and self-reliance. Therefore, she surpasses the limits of Cinderella, who is gendered by the hegemony, and sheds light upon how fairy tales construct gender-appropriate behaviors in society.

Keywords: Comparative Children's Literature, Fairy Tale Studies, Gender, Cinderella, The Magical Little Date Tree
\end{abstract}




\section{Introduction}

I would go so far as to say that even before slavery or class domination existed, men built an approach to women that would serve one day to introduce differences among us all.

Claude Lévi-Strauss

Famous British brand Harrods, in its 2019 summer campaign, used the slogan for Miu Miu glass slippers: “THRILL SEEKERS | Cinderella's glass sleepers ain't got nothing on these", and at the very beginning of 2020, its slogan was again Cinderella:" THRILL SEEKERS | Footwear Fit for Cinderella. You Shall Go to The Ball"1. Why these glass slippers are still with us? Why not only the fashion industry but different industries even in the millennium age allude to Cinderella? What is the success story behind the veil? Why is her story still vibrant, enticing and alluring to women of all ages? The answers will illuminate the entire story behind the implicit political agenda of fairy tales; the socializing power of the discourse of the dominant ideology, the hegemony, which constructs the gender roles in society: the very helpless, devoted, dependent female figure who wishes to be saved, as opposed to the independent, self-reliant, powerful male figure who is ready to rescue her. Cinderella's story can be interpreted as the most salient example of how the gender roles are constructed by the dominant ideology in a society through the discourse of fairy tales, because her story is a kind of emphatic space of women all around the world. The glass slippers, the pumpkin or Cinderella's beautiful dress implies so much more to the female audience ${ }^{2}$. However, the traditional construction of gender roles in fairy tales, represented by Cinderella, can be reversed through a comparative analysis of Grimm's Ashputtel and Giuseppe Pitré's The Magical Little Date Tree ${ }^{3}$. Through the discourse he uses, Pitré's reversal of gender roles both unveils and inverts the implicit political agenda in fairy tales: the constructed dependent female mind and body captivated by the dominant

1 https://www.instagram.com/p/B7JgDyt|E8L/

2 In this study, the fairy tale Ashputtel will be analyzed, but the tittle "Cinderella" will also be used throughout the study, which has become an umbrella term for the various versions of the tale and for fairy tale studies.

3 Giuseppe Pitré was a historian, politician and doctor. The term "demopsicologia" was coined by him to indicate to the scholar who collects and catalogues folk tales. He contributed to the establishment of the study of popular traditions in Italy as an independent discipline. (Zipes, 2017) For further reading see Jack Zipes (2017). The Extraordinary Giuseppe Pitré. In Zipes, J. (Ed.), Giuseppe Pitré, Catarina The Wise and Other Wondrous Sicilian Folk \& Fairy Tales (pp. 1-11). London: University of Chicago Press. 
discourse and its transformation into a self-reliant and independent gender: female ${ }^{4}$.

The comparative analysis of these two tales is significant in the sense that the difference between the discourse of the Grimms and Pitré, and the way in which they portray sexual roles, illuminate how traditional fairy tale culture, represented by the Grimms, aims to design women in a negative manner. To achieve this, they portray weak, passive, helpless, obedient beautiful young women in their tales, who are waiting for their'prince charming' in order to be rescued. They are not in control of their own destinies, do not have the ability to choose, the only thing they have in their hands is the magic which rewards their passivity and, in this case, transforms the young woman in rags into the beautiful, lucky princess who rises from the cinders. The transformation process includes a subtle conscious act which is the transformation of a gendered female identity constructed by patriarchy. When Ashputtel is compared with the Italian version of the tale, The Magical Little Date Tree by Pitré, it becomes patent that the suppression process of women, through the definition of sexual roles by the patriarchal discourse created by the Grimms, can be both altered and reversed. Deriving its origin from Italian culture, which represents the first modern printed example of European fairy tale tradition in Southern Italy, Naples, The Magical Little Date Tree posits the view that the sexual roles designed for women is not a destiny ${ }^{5}$.

4 In the story of Cinderella, the interaction among the other texts should be taken into account as there is not one but many Cinderella's written by different authors, such as; Perrault, Grimm's, Pitré, Disney's version. Kristeva explains this as intertextuality, deriving its origin from Bakhtinian notion of intertextuality, where "several utterances, taken from other texts intersect and neutralize one another" (1980, p. 36). Kristeva, like Bakhtin, underlines the fact that a text has various dynamics and it is heterogenous. In relation, the comparative analysis of the two texts, elucidate what makes Pitré's text different, how he tries to create change through the portrayal of an extraordinary Cinderella, Ninetta, who is no longer the girl in cinders but an independent woman.

5 Giovanni Francesco Straparola's Pleasant Nights (Le piacevoli notti) (1555) is regarded as the first known work where fairy tales appeared in print, which inspired important storytellers such as the Grimm's and Charles Perrault. Giambattista Basile, from Naples like Straparola, also influenced famous storytellers. Especially his work II Pentamerone (1634) has been regarded as one of the most influential works in fairy tale genre. Basile's version of the tales such as Cinderella and the Sleeping Beauty also gave inspiration to the Grimm's and various other storytellers. 


\section{The Theoretical Roots of Gender Studies in Fairy Tales}

But, you will say, 'gender' is a European word! Indeed. Gayatri C. Spivak 5, $2006^{6}$

Beginning with the women's liberation movement in the 1960s, the traditional interpretation of fairy tales has dramatically changed ${ }^{7}$. The increase in the importance of psychoanalysis in literature triggered the idea that the tales have tremendous socializing and psychologizing power on gender roles. One of the most eminent voices in gender studies, feminist psychologist Sandra Lipsitz Bem, fostered a turning point for the perception of gender roles". She underlines how a "nonconscious gender ideology" (1970) affects the way we interpret our roles in life. She created "Gender Schema Theory" and BSRI [Bem Sex Role Inventory] to elucidate how we become gendered:

It is hoped that the development of the BSRI will encourage investigators in the areas of sex differences and sex roles to question the traditional assumption that it is the sex-typed individual who typifies mental health and to begin focusing on the behavioral and societal consequences of more flexible sex- role self-concepts. In a society where rigid sex-role differentiation has already outlived its utility, perhaps the androgynous person will come to define a more human standard of psychological health. (Bem, 1974, pp. 161-162)

Bem uses gender schema and posits the view that we should subvert the process of gender schemes and should foster the creation of "gender-aschematic" children (Bem,1998). Bem's conception of "androgynous," a person encapsulating both masculinity and femininity, might have been regarded as obscure but as mentioned by Brown " $\mathrm{t}]$ he Women's Liberation Movement was very ready for Bem's psychometric innovation ... Women ... were ready for the refreshing idea that one could perfectly well be both assertive and sensitive" (1986, p. 317).

6 https://cadmus.eui.eu/bitstream/handle/1814/8066/RSCAS_DL_2006_UHL_Spivak.pdf?sequence=1

7 "For me, as for numbers of women of my generation, the women's movement exhilarated and propelled us into awareness" (Chodorow, 2012, p. 2). Mentioned by Nancy Chodorow, before women's movement, fairy tales were analyzed as simple literary works written for the amusement of children.

8 Sandra Bem was an Emerita Professor of Psychology at Cornell University and lost her life in 2014. Her contributions to gender studies in psychology also created a new path for the literary analysis of fairy tales. 
The revolutionary developments in the analysis of gender have led many researchers to focus upon the impacts of fairy tales on children's attitudes and perceptions of gender (Bettelheim 1976; Rowe 1979; Zipes 1997; Joosen 2011; Tatar 2003)' ${ }^{9}$, and how the discourse of fairy tales constructs our perceptions of gender-appropriate behavior in society ${ }^{10}$. Many posit the idea that fairy tales portray female subordination as "romantic myths" (Rowe,1979, p. 214), therefore creating a kind of Cinderella-like women in life who are waiting passively, depending upon the male power in order to be rewarded at the end. The portrayal of the demure female characters is mainly attacked by Marcia Lieberman's article, "Someday My Prince Will Come: Female Acculturation through Fairy Tale" (1972) which can be regarded as a milestone and a turning point in fairy-tale criticism. Written as a reaction against Alison Lurie's "Fairy Tale Liberation" (1970), Lieberman criticizes the negative influences of the ideology of traditional fairy tales. She suggests that "Millions of women must surely have formed their psycho-sexual self-concepts, and their ideas of what they could or not accomplish, what sort of behavior would be rewarded, and the nature of reward itself, in part from their favorite fairy-tales" (1972, pp. 186-87). Colette Dowling, an American therapist in the same period, theorized this in her study The Cinderella Complex. Women's Hidden Fear of Independence (1981). Her psychological reading of Cinderella's story and the adaptation of it into the daily lives of millions of women answers the question of why Cinderella is still with us and will be forever. In her masterpiece, Dowling defines the Cinderella Complex, also known as the Cinderella Syndrome, which has become an important terminology used in psychology. She further comments that deriving its origin from the fairy tale Cinderella, women, unconsciously, physically and mentally gain a kind of "neurotic dependency," "learned helplessness", "fusion," which is the fear of separation, "blind devotion", and "the wish to be saved" (Dowling, 1981, pp. 111, 112, 144, 135, 15). It might not be misleading to propose the idea that fairy tales stand at the very center of the construction of gender roles; the creation of a robot who is defined as 'woman' by the dominant ideology.

It is patent from reading fairy tales that the perspective of feminist criticism and psychoanalytic approach have become maverick proponents of understanding how

9 As mentioned by Cordelia Fine "[i]n the young child's world, gender is the social category that stands above all others, right from the start...And, unlike adults and older children, younger children don't tend to have other social categories like jock, doctor, Christian, or artist with which to identify. The drive for group belonging may explain why young children insist on girlish or boyish behavior or dress even in the face of parental displeasure..." (2010, p. 228)

10 German pedagogue Otto Gmelin intensifies the criticism in fairy tale studies and claims that the tales teach children 'sexism' and 'capitalism.' For further reading see Otto F. Gmelin (1995). Böses kommt aus Marchen. Die Grundschule, 3.3, pp. 124-31. 
the discourse of the tales construct our perceptions of gender. It is at this point, that 'cultural materialism', which was developed in the 1970s and 1980s parallel to the momentum in feminist and psychoanalytic criticism, has proposed a powerful approach to analyze the tales ${ }^{11}$. Cultural materialists reject the idea "that literary criticism exists in a privileged scholarly realm 'above' politics," instead they assert that "all readings are political readings" (Marlow, 2017, p. 2). Therefore, cultural materialists suggest the idea that literary criticism should consider the political and socio-economic dynamics of the context of a text. Reading fairy tales from the lenses of the cultural materialist approach encourages a political stance which underlines the importance of "customs,"'manners," "political and social theory" (Williams, 1960, pp. 272-273) while analyzing a text. The reason why the cultural materialist approach is well suited to fairy tale studies is due to the fact that it stresses the idea that the dominant ideology is "the very terms in which we perceive the world" (Dollimore, 2010, p. 9). As a reaction against this, cultural materialists "want to help make a difference" especially for the "marginalized gender, sexual, racial, political and religious groups" (Marlow, 2017, p. 3). Deriving their origin from Marxist and Foucauldian philosophies, they locate 'power' and 'ideology' at the center of their analysis ${ }^{12}$. Kate Millet, in 1969, defines this as "sexual politics" to underline the need of analyzing sexual relationships from a political stance. She asks the important question:

In introducing the term "sexual politics", one must first answer the inevitable question "Can the relationship between the sexes be viewed in a political light at all?..."The term "politics" shall refer to power-structured relationships, arrangements whereby one group of persons is controlled by another. (2000, p. 122)

In relation to these, the comparative analysis of Ashputtel and the Magical Little Date Tree illuminates the fact that Giuseppe Pitré, through his portrayal of Ninetta, achieved to act as a cultural materialist, even in the $19^{\text {th }}$ century, and wanted to create a difference

11 According to Gürsel Aytaç the plural investigation method enables the researcher, who analyzes the texts comparatively, to benefit from various methods instead of depending upon just one method (Aytaç, 2019, p. 101).

12 Jonathan Dollimore and Alan Sinfield postulate the view that "[a] combination of historical context, theoretical method, political commitment and textual analyses. Historical context undermines the transcendent significance traditionally accorded to the literary text and allows us to recover its histories; theoretical method detaches the text from immanent criticism which seeks only to reproduce in its own terms; socialist and feminist commitment confronts conservative categories in which most criticism has hitherto been conducted; textual analysis locates the critique of traditional approaches where it cannot be ignored. We call this 'cultural materialism' (1994, p. vii). 
for women, reverses gender roles theorized by the powerful ideology and refuted the idea that the designed gender, female, is the destiny of women ${ }^{13}$.

\title{
2. The Demolition of the Prince / The Rise of the Princess
}

\author{
Where there is power, there is resistance. \\ Michel Foucault ${ }^{14}$
}

The power of storytelling encapsulates the transformation of the magical realm into the reality of our lives which gives shape to both the world we are forced to live in and the identity we construct. It might not be misleading to underline the power of storytelling in our lives as "[w] hen the wonderful happens, when a holiday abroad is a splendid success or an unlikely romance ends happily, we commonly explain it was 'just like a fairy tale'"'(Opies, 1974, p. 11). When the implicit political agenda is realized, it becomes explicit"[w]hy should this story [Cinderella] attract so many tellers, capture so many reader and listeners? What is there about it that cuts through major differences of time, place and culture?" (Ulanov \& Ulanov, 1983, p. 13).

The significance of Ashputtel's story lies under the fact that it portrays the traditional construction of gender roles in fairy tales in two different ways. The first one is the construction of a helpless, passive physical body who becomes the slave of the stepmother and the stepsisters. The second one is the construction of a female language which is the signifier of silence as it is lack ${ }^{15}$. That is the reason why, at the very beginning of Ashputtel's story, she is "the poor little girl" (Grimm's, 2016, p. 220) whose fine clothes are taken from, and she is forced to live in the kitchen.

There, she was forced to do hard work; to rise early before daylight, to bring the water, to make the fire, to cook and to wash. Besides that, the sisters plagued her in all sorts of ways, and laughed at her. In the evening

13 In recent years the researchers have begun to underline the lack of comparative studies in children's literature (Atalay, 2019) as most of the scholars have ignored the importance of this area on an international basis. For an elaborate reading on comparative studies in children's literature see İrfan Atalay (2019). Karşılaştırmalı Edebiyat. İstanbul: Hiper Yayın. pp. 111-59.

14 (Foucault, 2020, p. 79).

15 In fairy tales, trying to find out a language which portrays an independent female character is like the child in the Lacanian symbolic order, the world of language, who is in search of a 'lost object' she is trying to refind. Ninetta's use of language to resist the hegemony of culture can be read as the need of the child to use language in order to restore the lack in the symbolic order. 
when she was tired, she had no bed to lie down on, but was made to lie by the hearth among the ashes; and as this, of course, made her always dusty and dirty, they called her Ashputtel. (Grimm's, 2016, p. 220)

According to the Cinderella Complex, she experiences "the great flush of comforting domesticity..." as domestic activities are regarded as "safe", and she does not have to cope with "stress" (Dowling, 1981, p. 83, 9, 10) as she is not part of social life. Colette Dowling defines this through giving an example from Simone De Beauvoir's statement: "In this insanity...the woman is so busy she forgets her own existence" (as cited in Dowling, 1981, p. 89). Therefore, the first dimension of gender roles about Ashputtel is the passive female body captivated at home, dealing with household activities, which calls for the sacrifice of social mobility. The female body is lack, as it is not in control of its own destiny. Accordingly, she becomes the symbol of "... [women] [who] fear setting a personal direction. They fear movement, discovery, change-anything that is unfamiliar and unknown. Most disabling of all, they're afraid of normal aggression and assertiveness" (Dowling, 1981, p. 80), and this will result in the Cinderella Complex in real life.

The second dimension is the construction of a female language which is lack. Ashputtel's lack of a language signifies the power of the discourse of the dominant ideology which silences women. When her step mother and her stepsisters decide to go to the ball in order to find their prince charming, she cannot even talk but just keeps crying. She is not permitted to go to the ball, as the dominant ideology is more powerful than her. And "at last she begged her mother very hard to let her go" (Grimm's, 2016, p. 221). It is patent that she cannot create a discourse in order to reverse the gender roles. She keeps waiting passively, some critics define this as the "watchful waiting" (Gould, 2006, p. 42). She just waits without fighting for her destiny. According to the Cinderella Complex, Dowling defines this as the desire of "the wish to be saved" (1981, p. 15). Ashputtel does not even have a name, therefore, an identity. She cannot move, she cannot talk, she cannot choose as she is the slave of the hegemony, the patriarchal discourse ${ }^{16}$. She is the stereotype of the shy, naïve, fragile, weak girl in ashes who does not even dare to say a word to the father because she has to go to the ball to find 'The

16 The concept of hegemony first appeared in 'The Southern Question' (1926) by Antonio Gramsci. He used the term to define "...one social group over the whole society exercised through so-called private organizations, such as the church, trade unions, schools" (Cammet, 1967, p. 204). He claims that "The Proletariat can become the leading and the dominant class to the extent that it succeeds in creating a system of alliances..." (Mouffe, 1979, p. 186) In this study, the term hegemony is used to refer the dominant patriarchal ideology in fairy tales, exemplified by Grimm's to subjugate the female audience through the portrayal of passive-submissive female characters who are the symbolic proletariats. 
Prince Charming' as she "...brought up to depend on a man and to feel naked and frightened without one" (Dowling, 1981, p. 20), and this is her Cinderella Complex. She puts her heart and soul into gaining the love and affection of her stepsisters and the stepmother, which is defined as "the blind devotion" (Dowling, 1981, p. 135) that means attachment to "the other" (Dowling, 1981, p. 47). She is the 'female body' who is coded by weakness, passivity and stability, and she belongs to the 'sex' who does not have a voice. On the other hand, Ninetta, who has a name, therefore an identity, reverses the gender roles, rebels against the dominant ideology, and manages to gain control of her body through language ${ }^{17}$. Unlike in Ashputtel's story, she does not have a stepmother, stepsister or a father who tries to make her passive. Her story is not the story of envy, the story of the lack or the story of "watchful waiting", but the story of independence and self-reliance.

\subsection{Cinderella Rises like a Phoenix from the Ashes: The Calibration of the Hegemony}

Michel Foucault's discourse on sexuality and power and Judith Butler's perception of gender have the potential to illuminate the possibility of denaturalizing gender roles and the reconstruction of specific power relations. They suggest ways in which to free individuals from becoming subjects of certain performances designed by culture. Their interpretations reveal how the discourse in fairy tales, which identify women as trapped entities, as shown in Ashputtel's case, can be altered, as it is not stable or determined. Pitré's portrayal of Ninetta is an example of this as she succeeds in reversing gender roles.

Michel Foucault, one of the most eminent voices in cultural materialism, in The Will to Knowledge. The History of Sexuality (1976), presents the idea that the history of sexuality does not focus mainly on history or sexuality. Instead, in order to highlight the history of sexuality, Foucault concentrates on the individuals who are designed and constructed as subjects of specific practices which are used to define sexuality. For Foucault, human beings are made subjects by the society, and it is the starting point of the history of sexuality because power is connected to sexuality as a cultural construct which is created by discourse. That is the reason why he underscores "the fundamental link between power, knowledge, and sexuality" (2020, p. 7). He asserts

17 While Ashputtel derives her name from the ashes, Ninetta's name is the diminutive of Antonietta and Antonetta. "This name means "highly praiseworthy" and derives from the root "Antonius," a Gens (Roman family name) to which (Marcus Antonius) belonged" (http://www.name-doctor.com/name-ninettameaning-of-ninetta-36390.html). Pitré might have chosen this name in order to empower his protagonist. 
that the way we interpret sexuality is erroneous. He underlines this with the "repressive hypothesis" to define how we develop our interpretation of sexuality. This hypothesis accepts the view that in the seventeenth century the bourgeois society somehow repressed sexuality and controlled individual's notions of sexuality. Foucault rejects the repressive hypothesis as he suggests that the discourse of sexuality was altered by science. In relation, "the objective is to analyze a certain form of knowledge regarding sex, not in terms of repression or law, but in terms of power" (2020, p. 76). He posits the view that the one who influences knowledge is the one who controls the power.

As opposed to the repressive hypothesis, he identifies power in terms of an active, dynamic, creative process which is not 'juridico-discursive', therefore, not repressive but productive. Instead of limiting power as a concept solely performed by the people who control knowledge, he suggests that;

Power is everywhere; not because it embraces everything, but because it comes from everywhere. And "Power," insofar as it is permanent, repetitious, inert, and self-reproducing, is simply the over-all effect that emerges from all these mobilities, the concatenation that rests on each of them and seeks in turn to arrest their movement. (Foucault, 2020, p. 77)

Hence "because power is everywhere", and because it exists in all relationships, he claims that power does not epitomize itself totally as a repressive, negative concept. He challenges the assumption that "you are always already trapped" (2020, p. 68). That is the reason why he does not identify power as a monolithic entity, controlled by one specific group against the other. Instead, he supports the view that power is everywhere, and asks the question: "Should it be said that one is always "inside" power, there is no "escaping" it, there is no absolute outside where it is concerned, because one is subject to the law in any case?" (2020, p. 78).

Foucault asserts that knowledge and power dynamics exist in all relationships of social life and have tremendous impact on sexuality. However, that does not mean that they are determined. Instead for Foucault, power is a dynamic, ongoing process which is prone to change through building new power relations. It can be assumed that;

The History of Sexuality is a history of the power effects that these discourses and practices of producing sexual knowledge have had. These 
power effects are significant; they include the constitution of sexualities, an invasive medicalization of human life, a transformation of the institution of the family, new relations towards death, biological racism and modern forms of war. The French subtitle of volume 1 of Foucault's The History of Sexuality, La volante da savoir (The Will to Know), is intended to call to mind Friedrich Nietzsche's Will to Power: as Foucault argues, the will to know about sex is intricately caught up with power relations and their effects. (Taylor, 2017, p. 11)

Following a Foucauldian lead, Judith Butler's work Gender Trouble: Feminism and Subversion of Identity (1990) is also a way to understand the possibility of the subversion of gender roles in fairy tales just like in the story of Ninetta. According to Butler, "Gender is the mechanism by which notions of masculine and feminine are produced and naturalized" (1999, p. 43). She endorses the idea that the categorization of differences among sexes are not natural but cultural, as they are the results of specific power formations and social practices. For Butler, gender is produced through our actions and the way we perform it. As it is a "doing" $(1999$, p. 33) process, a dynamic, changeable concept, like Foucault's interpretation of power, it might be "deconstructed and denaturalized" (Butler, 1999, p. 43). "She takes up Foucault's claim that the discourse of sexuality produces sex. She demonstrates that the categories of sex, gender, and desire are mutually reinforcing" (Schmidt, 2002, pp. 99-10). Therefore, instead of questioning the borders between a man and a woman, which is an unnecessary act for Butler, as the society strictly underlines it, she proposes a performative view of gender. The concept of "Performativity is not singular act, but a repetition and ritual, which achieves its effects through its naturalization in the context of a body, understood, in part, as a culturally sustained temporal duration" (Butler, 1999, p. 15). As performativity is a dynamic, ongoing process, it naturally encapsulates various new performances. She supports the view that gender is changeable, therefore reproduceable, and "performativity" is a way for that. For Butler, in order to "denaturalize" (1999, p. 20) gender and "the sense of gender reality" $(1999$, p. 22) among society, there are different ways which have the power to subvert gender roles.

In her story, Ninetta displays that subverting gender roles is possible. As women's role in society is defined through their sexual differences, she redefines her roles in two different ways. First, she creates a language of her own in order to devitalize the hegemony. Just like in Ashputtel's story, the father is a merchant and has to go oversees 
to sell his goods. When her father asks her what she wants him to bring her as a gift she says: "I want a beautiful little tree of dates. And if you forget this tree with dates, may your ship be prevented from moving forward or backward" (Pitré, 2017, p. 35). Her father does not take her seriously and forgets to buy the tree ${ }^{18}$. However, a terrible storm breaks out, and the ship is unable to move forward or backward. Ninetta reverses gender roles because it is no longer the female body or female language which cannot move forward or backward, but the patriarchal order. Secondly, she reverses the hegemony through her gendered body. Before her father went on his journey, he "had made this well for them, so they would not lack any water" (Pitré, 2017, p. 36). The idea of the lack is subverted by Ninetta because her sister "accidentally dropped her thimble into this well" (Pitré, 2017, p. 36), and she responds to them:

"Don't worry. Lower me down in the well, and I'll fetch the thimble."

"Are you joking?" the eldest sister said.

"No, I want to go down and fetch it."

They said, no. She said, yes. Back and forth they went. Finally, they had to lower her down into the well. (Pitré, 2017, p. 36)

Evidently, she manages to solve a problem without depending on others, which is something revolutionary in $19^{\text {th }}$ century traditional fairy tale discourse. "When she pulled her hand out of the water, she notices there is a light coming from a hole in the wall off to the side" (Pitré, 2017, p. 37). She sees a garden full of beautiful flowers and fruits. She picks some fruit and flowers, and then asks her sisters to pull her up. Her sisters are astonished at where she got the wonderful fruit and flowers. "On the third day, Ninetta insisted again, and told her sisters to lower her into the well. She had enjoyed the adventure of the previous day. They kept saying, no, and she kept saying, yes, until they had to lower her down" (Pitré, 2017, p. 38). Ninetta does not even know that this garden belongs to the Prince of Portugal and is recognized by him as she is trying to escape. The Prince falls in love with her and "couldn't find any peace of mind." (Pitré, 2017, p. 38) Ninetta seems to be "a real fairy" (Pitré, 2017, p. 38) for him. As he cannot catch her because of her speed, the symbolic use of fairy is significant in the sense that she is not associated with the beautiful princess waiting for the prince to save her, but the fairy who is in control of her

18 "Jung wrote an entire essay about the symbolism of the tree. He suggests that the tree represents a profile of the "self-depicted as a process of growth" (Jung 1967, par.304). He observes that it is commonly associated with the positive aspects of the Great Mother - the source of life, protection, shade, and nourishment (ibid., par. 350), De Vries notes that the hazel tree, along with the apple tree, is one of the most sacred of all trees and that it is related to the Great Goddess" (Zipes, 1997, p. 97). 
body. In order to cure the prince, the king decides to organize a ball to find Ninetta. While Ashputtel is crying and begging at home to go to the ball to meet the Prince, Ninetta refuses to go to the ball even though her father insists to her that the king will kill him if he does not bring one of his daughters. She still refuses to go and says:

It doesn't matter to me. Besides, who knows that you have three daughters? Pretend that you only have two. They argued back and forth until Ninetta won and remained at home with her little tree of dates which were her delight. (Pitré, 2017, p. 39)

Ninetta is the one who explores, discovers, experiences, therefore, neutralizes the gender perception of the dominant ideology. She is not the girl in cinders who wishes to be saved. Ashputtel's sense of dependence and lack of self-confidence is transformed by Ninetta into a sense of independence and self-confidence. She is not the one who wishes to be saved, as she is in control of her body, therefore, she reverses gender roles. As highlighted by Dowling, "confidence and self-esteem are primary issues in women's difficulties with achievement. Lack of confidence leads us into the dark waters of envy" (Dowling, 1981, p. 127). In Ninetta's story, she does not have to cope with either the jealousy of her sisters nor other characters preventions, as she is strong enough to resist them ${ }^{19}$.

It is important to underline the socio-political forces which triggered Pitre's portrayal of Ninetta as a woman who has an inner power to resist suppression. She is the very reflection of the Risorgimento Period, which is called 'Italian Unification' in history. The Risorgimento Period was a political and social movement in the nineteenth century which called for the romantic, nationalistic, ideals of an Italian Renaissance. During this period, many intellectuals and revolutionaries gathered together under the organizations of women. That was the reason why, for the first time in Italy, women became active participants of political life. The air of freedom also affected the literary world in a positive way, as one of the main aims of the era was to give power to women, in order to build a stronger and a more competitive nation. The difference between the discourse of Pitré and the Brothers Grimm lies under the fact that, while Italy supported the

19 Jack Zipes proposes the view that "since women told most of these tales, [Pitré's tales] they tend to be candid and stark depictions of extraordinary young woman who cleverly shape their destinies, in contrast to the male literary versions of Straparola, Basile, Perrault, and the Brothers Grimm. In "Date, Oh Beautiful Date", for instance, the sprightly Ninetta (Cinderella) toys with a prince in his garden until he falls desperately in love with her. She constantly evades him, even at three different balls, until he is at his wits' end. The prince's father must intervene to save his son's life, and he actually proposes to Ninetta for his son" (Zipes, Irresistible, 2012, p. 128). 
empowerment of women in this era to form a better nation, the bourgeois society in German culture intended to suppress women.

\section{A Journey to Independence: The Neutralization of Gender Roles}

Foucault proposes that a kind of revolutionary shift can only be achieved through resistances that "are spread over time and space at varying densities, at times mobilizing groups or individuals in a definitive way, inflaming certain points of the body, certain moments in life, certain types of behavior" (2020, p. 79). Hence, Ninetta's rebellion cannot be regarded as an individual act, but as a social rebellion which can affect an entire genre that triggers change in gender roles. She refuses to go to the ball because of the punishment system of the bourgeois, represented by the King, and does not allow her family members attempt to manipulate her individualism. Therefore, she subverts the 'magisterial' authority. Kate Millet defines this in terms of Max Weber's "asherrschaft", "a relationship of dominance and subordinance" (2003, p. 123). Depending upon Weber's notion of power-relationships, she posits the view that throughout history,

Domination in the quiet sense of power, i.e. the possibility of imposing one's will upon the behavior of other persons, can emerge in the most diverse forms. In this central passage of Wirtschaft and Gesellschaft, Weber is particularly interested in two such forms: control through social authority (patriarchal, magisterial, or princely) and control through economic force. In patriarchy, as in other forms of domination, "that control over economic goods", i.e. economic power, is a frequent, often purposively willed, consequence of domination as well as one of its most important instruments. (Millet, 2000, p. 148)

Ninetta subverts the traditional social authority in an untraditional manner. She does not want to serve her beauty to the King's son, therefore, refuses to go to the ball unlike the Ashputtel, who is begging and crying to go, as she knows that her only chance to survive in life is to be chosen by the Prince. As Marx and Engels assume "the bourgeoisie cannot exist without constantly revolutionizing the instruments of production, and thereby the relations of production, and with them the whole relations of society" (2012, p. 38). The bourgeois represented by Grimm's' discourse in fairy tale studies does this through producing a female body like a Barbie-doll; ideal, perfect, weak, submissive, demure, passive, which is identified as female. 
When the passive Ashputtel uses magic and succeeds in going to the ball, she is transformed into a different woman. At the ball, everyone thought that this beautiful lady "must be some strange princess, she looked so fine and beautiful in her rich clothes; and they never once thought of Ashputtel, taking it for granted that she was safe at home in the dirt" (Grimm's, 2016, p. 224). She is no longer the girl in ashes, but a new woman in a beautiful dress that is a design of the dominant ideology. Susan Faludi defines this strategy, which derives its origin in fairy tales, especially from Cinderella, and asserts that "by inventing a "dress-for-success" ideology and foisting it on women, the dominant ideology creates a "conscious political program" (2006, pp. 186, 212). Ashputtel does not feel confident or independent because she knows that the ideology, 'the conscious political program' whispers to her that she will be chosen on condition that she is obedient and fits into the ideal beauty category. The ideology allows her to become the beautiful princess, but will also turn her into the girl in ashes at the end. That is the reason why she escapes from the Prince, because she knows that he will not love her if he sees her true-self and body ${ }^{20}$. Feminist scholar Iris Young follows phenomenologist Merleau-Ponty, who "reorients the entire tradition of that questioning by locating subjectivity not in mind or consciousness, but in the body" (2005, p. 35 emphasis is original). Ashputtel's story is a marvelous example of that. Her experience of transformation is not a natural one as it is controlled and designed by the hegemony. As indicated by Nancy Chodorow, "... because men have power and cultural hegemony in our society, a notable thing happens. Men use and have used this hegemony to appropriate and transform these experiences" (Chodorow, 1997, p. 17).

On the other hand, Ninetta's physical appearance does not change, as she is an independent, self-reliant woman, she does not need to be changed in order for the Prince to be attracted to her, as he loves her at first sight. He sees her as the bold young lady who dares to take flowers and fruit from his garden and manages to escape each time. Ninetta's transformation is different from Ashputtel's, as it is not designed according to the rules of the dominant ideology. The way she acts'creates a revolutionary re-constitution of society.' Her transformation while she is preparing for the ball might be read in terms of Deleuze's'notion of becoming.'Rosi Braidotti defines this as with the following statement:

20 Giving example from Bridget Jones, Angela McRobbie claims that even in the age of postfeminism women are still afraid of being independent and want to depend on men in order to find a place in society. She suggests the view that "despite the choices she has, there are also any number of risks of which she regularly reminded. The risk that she might let the right man slip from under her nose, so she must always be on the lookout, prioritizing this over success in the workplace. The risk that not catching a man at the right time might mean she misses the chance of having children (her biological clock is ticking). There is also the risk that, without a partner she will be isolated, marginalized from the world of happy couples" $(2009$, p. 20). 
It is linked to his stated aim of imaging the activity of thinking differently, that is, redefining the scene of philosophy. Deleuze's notion of becoming is adapted from Nietzsche; it, therefore, is deeply anti-Hegelian. Becoming is neither the dynamic opposition of opposites nor the unfolding of an essence in a teleologically ordained process leading to a synthesizing identity. The Deleuzian becoming is the affirmation of the positivity of difference, meant as a multiple and constant process of transformation. Both teleological order and fixed identities are relinquished in favor of a flux of multiple becoming. (1994, p. 111)

Ninetta's transformation is also a constant and multiple one. Ninetta never excludes her real self. While she transforms into a woman in beautiful clothes, she does not become a new woman, but welcomes all the other women she carries in herself; the one with the daily clothes trying to find water in the well, the one who picks up flowers from the Prince's garden or the one at the ball. She dynamically becomes Ninetta and creates difference, as she symbolizes a constant process of transformation for the female audience. When she enters the ball, everyone knows that she is Ninetta, and the Prince immediately recognizes her. "'Madonna!" one of them said. "She looks exactly like Ninetta" (Pitré, 2017, p. 43). When she returns home, one of her sisters says: "Ninetta, Ninetta, what a beautiful ball! There was a lady there who looked just like you! If we hadn't known that you were here, we would have said that it was you!" (Pitré, 2017, p. 42). Her transformation is not the transformation of the ideal female figure of the hegemony, but the transformation of gender roles. Her dialogue with the prince indicates this:

"My lady, how are you?"

"Like the winter," she replied.

"What do you call yourself?"

"By a name."

"Where do you live?"

"In a house with a door."

"In what street?"

"In the street with a cloud of dust."

"How strange you are! You will be the death of me."

"May you bite the dust!"

(Pitré, 2017, p. 41) 
She both controls the language and the body, therefore, gains the power from the hegemony. She dances with the Prince the entire night, "The prince got tired, but Ninetta remained lively because she was enchanted" (Pitré, 2017, p. 41). Dancing is joyful for her as she does not know what will happen next. She celebrates her true-self and body. The reversal of gender roles is quite patent in the dance scene, as the female body is the more energetic and powerful one, while the male body is the inferior one. "It is well known that the body politic, as a generic term still used today to indicate the state, owes its origin to an ancient metaphorical tradition based on the analogy between the human body and the political form of the community" (Cavarero, 2002, p. 99), but the hegemony which politicizes the female body is subverted by Ninetta.

At the end of their stories, while Ashputtel is waiting to be saved, Ninetta creates her own rules to subvert hegemony. As Ashputtel obeys the rules of hegemony, the Prince says; 'I will take for my wife the lady that this golden slipper fits' (Grimm's, 2016, p. 226). Her obedience, her weakness, her submissiveness are the elements which suit the golden slippers. 'The Golden Slipper' is the very symbol of the cultural norms that fairy tales teach women ${ }^{21}$. On the contrary, Ninetta is the one who looks "like gold" (Pitré, 2017, p. 41). She does not need the golden slippers to survive. Instead she uses gold in a different way.

...she took out a number of sacks with gold coins that she had in the carriage and threw them in the face of the servants, who broke each other's noses and hit one another in the eyes to get at the gold. As a result, the servants could not follow the carriage and had to crawl back to the palace like whipped dogs. (Pitré, 2017, p. 43)

She has money, she has the ability to use her mind and body, therefore, changes the rules of the game. The body of Ninetta is not passive, it resists, rejects, jumps, moves, while Cinderella keeps waiting passively for the golden slippers. As Castelnuovo and Guthrie note, "[b]ecause women's nature was believed to be particularly associated

21 "William Durham (1992) has forcefully defended the ideal definition of culture, insisting that a distinction must be drawn between culture and human behavior. Durham is not alone; a majority of contemporary anthropologists holds that culture consists exclusively of shared and socially transmitted ideational or mental entities, such as values, ideas, beliefs and the like, in the mind-things under the umbrella term meme invented by Richard Dawkins (1976). For Dawkins meme is the fundamental unit of information that is stored in the brain, transmitted through social learning, and acted upon by the selective forces of cultural evolution" (Harris, 1999, p. 20). Gender roles can be regarded as the 'meme' in fairy tales which is transmitted to the female audience. 
with their bodies, females were relegated to an inferior position" (1998, p. 9). Ninetta alters this view, and reverses gender roles. She is not associated with her body but with her intelligence. On the other hand, the Prince's body is inferior; weak, passive and not in control of itself just like Ashputtel. When she tries on the golden slippers, and they fit, the Prince declares that '[t]his is the right bride' (Grimm's, 2016, p. 228). She fits into the design of the hegemony as the Prince says; "I will take for my wife the lady that this golden slipper fits" (Grimm's, 2016, p. 226). However, at the end of her story, Ninetta is not the one who is waiting to be chosen, but the one who demands. She conditionally agrees to marry the Prince stating; "I'm not free. I'm obliged to my father and two sisters" (Pitré, 2017, p. 45), and the King accepts the condition. American feminist Judith Fetterly suggests in The Resisting Reader (1978) "to create a new understanding of our literature is to make possible a new effect of that literature on us. And to make possible a new effect is in turn to provide the conditions for changing the culture that the literature reflects" (pp. xix-xx). Apparently, through his portrayal of Ninetta, Pitré succeeds in altering the culture, the traditional gender roles designed for women even in the nineteenth century. Ninetta is not the one who is experiencing the Cinderella Complex, but the one who experiences independence and self-reliance from start to end.

\section{Conclusion}

Since the women's liberation movement in 1960s, fairy tale studies have gained a new momentum. They are no longer regarded as a literary genre designed for the fun of children, but a conscious ideology which has the power to both socialize and psychologize the gender roles in society. One of the most salient examples of this is the tales of the Brothers Grimm, whose works can be regarded as the voice of the dominant ideology which constructs the gender roles. Among their fairy tales, Ashputtel can be regarded as the most powerful indicator of how the discourse created in fairy tales triggers the development of gender appropriate-behaviors in society. Widely known as Cinderella from Perrault's version, Ashputtel serves as a role model for millions of women who are implicitly designed as a weak, dependent, helpless gender expected to fit into the norms of both submissiveness and beauty. Colette Dowling defines this as the Cinderella Complex, which has later become a psychological term, and asserts that millions of women have been experiencing that psychological dependency which leads to'lack of self-esteem,' socializing only within the borders of home, 'blind-devotion' and 'the wish to be saved' (Dowling, 1981). 
In addition to the psychological dimensions of the impacts of fairy tales on women, researchers have begun to focus on the socio-cultural dynamics of the tales, which design a female body and psyche ready to be passive. In order to analyze these dynamics, the comparative analysis of Giuseppe Pitré's The Magical Little Date Tree and Grimm's Ashputtel, through the lenses of plural investigation method, postulates the idea that societal-gender roles designed by the hegemony can be altered and reversed through a new discourse. In his tale, Pitré portrays Ninetta, the Italian version of Cinderella, as a powerful, independent, self-reliant young lady, who has self-esteem and has the capacity to shape her own destiny. While Ashputtel is experiencing the Cinderella Complex, wishing to be saved, blindly-devoted to her step mother and sisters, dependent on others as 'the second sex', Ninetta acts independently and reverses gender roles. The reversal of gender roles in Ninetta's story has two dimensions. The first one is, she does not passively wait for a miracle to shape her destiny, but fights and works for it. She uses her body independently, relying solely on herself, stressing self-reliance, jumps, moves, escapes, runs, fights therefore, subverts the traditional notion of the female body constructed for women in fairy tales, which is parallel to the passive one we have in society. The second dimension of her reversal of gender roles is her use of language. As opposed to the silent language designed for women by the hegemony, Ninetta creates a language that calls for a rebellion and resistance to the hegemony. While Ashputtel's passivity cannot create a change, Ninetta's resistance manages to alter the socio-political image of women.

The comparative analysis of the two versions of the tales asserts the view that fairy tales have more powerful effects on the construction of gender roles in society than one can surmise. When the ideology, therefore, the discourse of the tales is reversed, just like Pitré does, the construction of gender roles can change on behalf of women, and help the development of a psychologically and physically superior gender who are aware of their potential, just like Ninetta.

Peer-review: Externally peer-reviewed.

Conflict of Interest: The author has no conflict of interest to declare.

Grant Support: The author declared that this study has received no financial support.

Hakem Değerlendirmesi: Dış bağımsız.

Çıkar Çatışması: Yazar çıkar çatışması bildirmemiştir.

Finansal Destek: Yazar bu çalışma için finansal destek almadığını beyan etmiştir. 


\section{References}

Atalay, I. (2019). Karşılaştırmalı edebiyat. İstanbul: Hiper.

Aytaç, G. (2019). Karşılaştırmalı edebiyat bilimi. Ankara: Doğu Batı.

Bem, S. L. \& Bem, D. J. (1970). Training the woman to know her place: The power of a nonconscious ideology. In S.

Cox (Ed.), Female Psychology: The Emerging Self (pp. 180-191). Chicago: Science Research Associates.

Bem, S. L. (1974). The measurement of psychological androgyny. Journal of Consulting and Clinical Psychology, $42,155-162$.

Bem, S. L. (1998). An unconventional family. New Haven: Yale University Press.

Bettelheim, B. (1975). The use of enchantment: The meaning and importance of fairy tales. New York: Vintage Books.

Braidotti, R. (1994). Nomadic Subject. Embodiment and sexual difference in contemporary feminist theory. New York: Colombia University Press.

Brown, R. W. (1986). Social psychology (2nd ed.). New York: Free Press.

Butler, J. (1999). Gender trouble. Feminism and the Subversion of Identity. New York: Routledge.

Castelnuovo, S. \& Guthrie S. R. (1998). Feminism and the female body: liberating the amazon within. Boulder and London: Lynne Rienner Publishers.

Cammet, J. M. (1967). Antonio gramsci and the origins of italian communism. California: Stanford UP.

Cavarero, A. (2002). Stately bodies. Literature, philosophy and the question of gender. (Trans Robert de Lucca \& Deanna Shemek, Trans.). Ann Arbor: Michigan UP.

Chodorow, N. J. (1997). Gender, relation, and difference in psychoanalytic perspective. In Meyers, D.T. (Ed.), Feminist Social Thought: A Reader (pp.7-21). New York: Routledge.

Chodorow, N. (2012). Individualizing gender and sexuality. Theory and Practice. New York: Routledge.

Cordelia, F. (2010). Delusions of gender. how our minds, society, and neurosexism create difference. New York: Norton

Dollimore, J. \& Sinfield, A. (1994). Political shakespeare: New essays in cultural materialism. Manchester: Manchester UP.

Dollimore, J. (2010). Radical tragedy: Religion, ideology and power in the drama of Shakespeare and his contemporaries. Houndmills: Macmillan.

Dowling, C. (1981). The Cinderella complex. Women's hidden fear of independence. New York: Pocket Books.

Faludi, S. (2006). The undeclared war against women. New York: Three Rivers Press.

Fetterly, J. (1978). The resisting reader: A feminist approach to american fiction. Blooming: Indiana UP.

Foucault, M. (2020). The will to knowledge. A history of sexuality I. (R. Hurley, Trans.). London: Penguin. [E-book version]. Retrieved from http://books.google.com.tr

Gould J. (2006). Spinning straw into gold. What fairy tales reveal about the transformations in a woman's life. New York: Random.

Gramsci, A. (2005). The southern question. antonio, D. (Ed.). Verdicchio, P. (Trans.). Guarnica: Toronto.

Grimm's, J. L. C. and Grimm's W. C. (2016). Grimm's Fairy Tales. London: MacMillan. 
Harris, M. (1999). Theories of culture in postmodern times. Walnut Creek, AltaMira.

Joosen, V. (2011). Critical \& creative perspectives on fairy tales. An intertextual Dialogue between Fairy-Tale Scholarship and Postmodern Retellings. Detroit: Wayne State University Press.

Kristeva, J. (1980). Desire in language: A semiotic approach to language and art. Roudiez, L.S. (Ed.), Thomas G, Alice, J. \& Roudiez, L. S. (Trans.). New York: Columbia University Press.

Lieberman M. (1972). 'Some Day My Prince Will Come:' Female Acculturation through the Fairy Tale.' College English, 3, 383-395. Retrieved from https://www.jstor.org/stable/375142.

Lurie, A. (1970). Fairy tale liberation. The New York Review of Books, December 17.

Marks, K. \& Engels, F. (2012). The communist manifesto. A modern edition. London: Verso.

Marlow, C. (2017). Shakespeare and cultural materialist theory. London: Bloomsbury.

McRobbie, A. (2009). The aftermath of feminism: Gender, culture and social change. London: Sage.

Millet, Kate. (2000). The theory of sexual politics. In C. Barbara (Ed.), Radical feminism. a documentary reader (pp.

122-154). New York: New York UP.

Mouffe, C. (1979). Gramsci and marxist theory. London: Routledge \& Kegan Paul.

Opies, P. \& I. (1974). The classic fairy tales. London: Oxford University Press.

Pitré, G. (2017). Catarina the Wise and Other Wondrous Sicilian Folk and Fairy Tales. (Jack Zipes, Trans \& Ed.).

London: University of Chicago Press.

Rowe, K. (1979). Feminism and fairy tales. In Jack Zipes (Ed.), Don't bet on the prince. contemporary feminist fairy tales in America and England (pp. 209-223). New York: Routledge.

Schmidt, D. (2002). (Ed.). Feminism, foucault, and embodied subjectivity. Albany: State University of New York Press.

Tatar, M. (2003). The hard facts of the grimms' fairy tales: Expanded second edition. Princeton and Oxford: Princeton University Press.

Taylor, C. (2017). (Ed.). The routledge guidebook to Foucault's the history of sexuality. New York: Routledge.

Ulanov, A. \& Ulanov, B. (1983). Cinderella and her sisters. The envied and the envying. Philadelphia: The Westminster Press.

Williams, R. (1960). Culture and society, 1780-1950. New York: Anchor Books.

Young, I. M. (2005)."Throwing like a girl" and other essays in feminist philosophy and social Theory New York: Oxford UP.

Zipes, J. (1997). Happily ever after: Fairy tales, children, and the culture industry. New York: Routledge.

Zipes, J. (2012). The irresistible fairy tale. The Cultural and Social History of a Genre. New Jersey: Princeton UP.

Zipes, J. (2017). The extraordinary Giuseppe Pitré. In Zipes, J. (Ed.), Giuseppe Pitré, Catarina The Wise and Other Wondrous Sicilian Folk \& Fairy Tales (pp.1-11). London: University of Chicago Press. 
